\title{
STUDYING MICROBIOLOGY OF RAIN WATER FOR OF THEIR USE IN ECONOMY
}

\author{
Monika Zdeb', Justyna Zamorska', Dorota Papciak' \\ 1 Treatment Plant and Water Protection Division, Department of Civil Engineering, Environmental Engineering \\ and Architecture, University of Rzeszow, Powstańców Warszawy 6 Av., 35-959 Rzeszów, Poland, e-mail: \\ mzdeb@prz.edu.pl, jzamor@prz.edu.pl,dpapciak@prz.edu.pl
}

Received: 2016.03.16

Accepted: 2016.06.01 Published: 2016.07.01

\begin{abstract}
Growing areas of sealed surfaces, rising water needs due to industry development, increasing populations, and climatic changes affect precipitation patterns and form a vision of the future in which meteoric water storage may become almost an obligatory activity. The aim of this paper was to identify the amounts and, to some degree, the quality of microorganisms present in rainwater collected from different types of rooftops of utility buildings in the spring-summer season. Apart from the classic culture plate method complemented by flow cytometry. The results of performed analyses explicitly show that rainwater collected from rooftops and directly from air prove to be microbially contaminated to a substantial degree, which includes pathogenic coliforms and faecal streptococci. Waters collected after dry periods also contained bacteria like Clostridium perfingens. The findings rule out the possibility of using rainwater collected from roof surfaces of utility buildings before its treatment.
\end{abstract}

Keywords: rainwater, microbial contamination, flow cytometry, plate method

\section{INTRODUCTION}

According to a definition found in Water Resources Law of July $18^{\text {th }} 2001$ (Journal of Laws no. 115 , point 1229 as amended), rainwater is considered in entirety as waste, and whether it is considered waste or not relies on the place of its origin - art. 9, point $14 \mathrm{c}$. When draining rainwater off to sewage we deal with rainwaters coming from a) surfaces permanently sealed, in which case the Water Resources Law classifies such water as waste and b) roofs, in which case the Water Resources Law does not include such water in the waste category. Within the meaning of the law, it can be stated that rainwater from roof is not "waste" regardless of the type of roofing and regardless of the type of building, because the rooftop "surface" is not a "pavement", which is part of the definition of so-called rain "waste" (art. 9, par. 1, point 14, letter c Water Resources Law; art. 3 point 38, letter c Environment Protection Law). This does not mean, however, that water is supposed to be considered free from chemical or microbial contamination.

Quality tests of rainwater to see if it is fit for use as a source of drinking water and for household/utility purposes indicate the same possibility. Normative values for heavy metals have not been exceeded. The extensive studies into the quality of meteoric water is not in keeping with the broad knowledge on its microbiological aspects despite the fact that the WHO (2004) recommends that water used for household purposes contain no more coliforms than $10 \mathrm{CFU} / 100 \mathrm{ml}$ in $95 \%$ of tested samples. Only few researchers study bacteriology and present adequate findings. They are concerned mostly bacteria which renders water unfit for human consumption. These bacteria are Escherichia coli and faecal streptococci [Lee i in., 2010; Amin i Han, 2011; Kaushik i Balasubramanin, 2012]. Very few researchers include in their studies of pathogenic strains such as: Staphylococus sp., Pseudomonas aeruginosa, Pseudomonas syringae, Streptococ- 
cus sp., Klebsiella pneumoniae, or Clostridium perfrigens [Nawaz i in., 2012, Gikas i in., 2012]. Coliforms and Escherichia coli always exceed normative values in the tested samples of rainwater collected from rooftops or terraces. The studies also included tests of rainwater from water collection system against the presence and count of Campylobacter- and Legionella-type bacteria. The results for most samples showed the amounts of bacteria merely on the level of detection (1 CFU/100 $\mathrm{ml}$ of water).

Moreover microbiological research methods for rainwater leave a lot to be desired. Often, the conclusions over the quality of rainwater rely on results obtained with simple methods such as agar plate method or even tube fermentation techniques [Helmreich i Horn, 2008].

The studies employed advanced test methods to study the microbial quality of rainwater collected from different types of rooftops. The findings helped to evaluate the possibilities of utilizing rainwater for household purposes or for agriculture.

\section{RESEARCH METHODS}

The studies were carried out in the springsummer season in 2015. Water was collected from roof gutter with different coats and inclination angle: $\mathrm{B}$ - concrete tile $\left(45^{\circ}\right), \mathrm{C}$ - ceramics tiles $\left(45^{\circ}\right), \mathrm{O}-$ galvanized sheet $\left(45^{\circ}\right)$, and $\mathrm{E}$ - epoxide resin (terrace $-2^{\circ}$ ). For control purposes, airborne water was collected - P. All five points of rainwater collection were at one of Rzeszów's suburban neighbourhoods of detached houses located in the near vicinity of farming land (50 to $200 \mathrm{~m}$ distance), and mechanicalbiological municipal waste treatment plant (1500 m). Samples were collected from each rainfall that occurred into sterile polyethylene containers opened during rain. Taking into account the washing away effect, portions of water were collected only after at least an hour-long, intensive fall. The samples were transported to the laboratory in a portable fridge in less than 6 hours. For each collected sample of water a series of microbiological assays (Table 1).

Coliforms and E. coli were assayed in a standard way using procedures provided for by the PN-EN ISO 9308-1 and PN-EN ISO 9308-2 norm. Likewise, assays were performed for faecal streptococci PN-EN ISO 7899-2. Bacteria from the coli group and E. coli were additionally assayed with the use of a chromogenic medium. The medium makes the coli bacteria grow fast due to a combination of proper peptones and the MOPS buffer. The combination of two chromogenic substrates reveals all intestinal bacteria and E. coli. Total number of bacteria was determined in accordance with PN-EN ISO 6222 also with an additional variant, where cultures are grown on agar supplemented $\mathrm{R}$ with extended incubation. Samples for cytometry analysis were prepared according to the own procedure. The difference between the number of all particles (assayed with Sybr Green) and the number of dead particles (assayed with propidium iodide) provides the overall number of living microorganisms.

\section{RESULTS AND DISCUSSION}

The conducted studies indicate the presence of considerable amounts of pathogenic bacteria in rainwater flowing over different rooftops as well as those collected directly from air [Cho and Hwang, 2011; Polymenakou et al., 2012]. In early spring season they are, however, much scarcer compared to warmer seasons. Similar correlations between air temperature and surface from which precipitation is collected has been observed by Lee et al., 2010, Amin and Han, 2011, arrived at similar numbers for coliforms and faecal streptococci in spring and summer seasons (Tables 1, 2, 3).

Also, research on the microbial quality of rainwater from tanks showed that $70 \%$ of samples contained excessive amounts of E. coli bacteria and faecal enterococci [Ahmed 2014]. Some authors also note the very high concentration of these bacteria - up to $500 \mathrm{cfu} / 100 \mathrm{ml}$ [Wilbers at al., 2013]

In early spring the source of highest contamination levels were concrete tiles and epoxide resin covering a terrace. Water collected from these surfaces after the winter period was found to contain active cells of anaerobic bacteria - Clostridium perfingens (Table 2). These organisms are an indication of an old faeces contamination and their presence on roof surfaces is rather rare. They may appear after longer periods with a lack of rain. In the case of tiles, their porosity may play a fundamental role in accumulating contaminants. For terraces, the marginal inclination angle prevents effective washing off with first instances of rain. 
Table 1. Methods and research apparatus for analysing the microbiological state of rainwater.

\begin{tabular}{|l|l|l|}
\hline \multicolumn{1}{|c|}{ Indicator } & \multicolumn{1}{|c|}{ Test method } \\
\hline $\begin{array}{l}\text { overall mesophilic and } \\
\text { psychrophilic bacteria } \\
\text { count }\end{array}$ & $\begin{array}{l}\text { plate culture and bacteria cultured on standard } \\
\text { nutrient media (nutritional agar) and enriched } \\
\text { ones (agar R); oxygen conditions }\end{array}$ & $\begin{array}{l}\text { Equipment } \\
\text { sterilizer, autoclaves, bacteriological culture } \\
\text { cabinet, incubator, scales }\end{array}$ \\
\hline $\begin{array}{l}\text { number of pathogenic } \\
\text { bacteria - Eschericha coli }\end{array}$ & $\begin{array}{l}\text { membrane filter technique and culture on } \\
\text { selective and differential media; oxygen } \\
\text { conditions }\end{array}$ & $\begin{array}{l}\text { sterilizer, autoclaves, bacteriological culture } \\
\text { cabinet, incubator, scales, a filtration kit }\end{array}$ \\
\hline $\begin{array}{l}\text { number of pathogenic } \\
\text { bacteria - Enterococci } \\
\text { (faecal streptococci) }\end{array}$ & $\begin{array}{l}\text { membrane filter technique and culture on } \\
\text { selective and differential media; oxygen } \\
\text { conditions }\end{array}$ & $\begin{array}{l}\text { sterilizer, autoclaves, bacteriological culture } \\
\text { cabinet, incubator }-37^{\circ} \mathrm{C}, \text { scales, a filtration kit }\end{array}$ \\
\hline $\begin{array}{l}\text { number of spore bacteria } \\
\text { Clostridium perfringens }\end{array}$ & $\begin{array}{l}\text { plate culture and cultures on nutrient, } \\
\text { selective, and differential media; oxygen } \\
\text { conditions }\end{array}$ & $\begin{array}{l}\text { sterilizer, autoclaves, bacteriological culture } \\
\text { cabinet, incubator }-37^{\circ} \mathrm{C},\end{array}$ \\
\hline $\begin{array}{l}\text { live and dead bacteria cell } \\
\text { count }\end{array}$ & cytometry analysis with fluorescent dye & $\begin{array}{l}\text { flow cytometer PARTEX, fluorescent dyes: Syto } \\
\text { culture cabinet, incubator }-37^{\circ} \mathrm{C}\end{array}$ \\
\hline
\end{tabular}

Table 2. Pathogenic bacteria count in rainwater - early spring (13 March 2015)

\begin{tabular}{|l|c|c|c|c|c|}
\hline \multirow{2}{*}{\multicolumn{1}{|c|}{ Indicator }} & \multicolumn{5}{c|}{ The number of bacteria in 100 ml water sample [cfu] } \\
\cline { 2 - 6 } & $\mathrm{P}$ & $\mathrm{B}$ & $\mathrm{C}$ & $\mathrm{O}$ & $\dot{Z}$ \\
\hline E. coli (standard substrate) & 2 & 0 & 0 & 0 & 1 \\
\hline E. coli (chromogenic substrate) & 7 & 0 & 0 & 0 & 3 \\
\hline streptococcus faecalis & 2 & 8 & 6 & 0 & 12 \\
\hline Clostridium perfingens & 0 & 1 & 0 & 0 & 1 \\
\hline
\end{tabular}

Table 3. Pathogenic bacteria count in rainwater - spring (11 May 2015)

\begin{tabular}{|l|c|c|c|c|c|}
\hline \multirow{2}{*}{\multicolumn{1}{|c|}{ Indicator }} & \multicolumn{3}{c|}{ The number of bacteria in 100 ml water sample [cfu] } \\
\cline { 2 - 6 } & $\mathrm{P}$ & $\mathrm{B}$ & $\mathrm{C}$ & $\mathrm{O}$ & 0 \\
\hline E. coli (standard substrate) & 41 & 47 & 55 & 7 \\
\hline E. coli (chromogenic substrate) & 54 & 35 & 2 & 47 \\
\hline streptococcus faecalis & 7 & 24 & 0 & 7 \\
\hline Clostridium perfingens & 0 & 0 & 0 & 0 \\
\hline
\end{tabular}

Escherichia coli, faecal streptococci, and $C$. perfingens are microorganisms found in large amounts in human and animal faeces. The presence of these bacteria in roof-collected water may be accounted for by faeces left by birds and small mammals (mainly in the case of the terrace) [Śmigielska, 2010]. Another potential sources of faecal microorganism contaminants are wind-transported soil particles coming from organically fertilized farming land and bioaerosol from freestanding biological reactors of the water treatment plant. This is even more probable considering the fact that the points of water sample collection are located east of the abovementioned potential sources of microorganisms and the prevailing type of wind is westerly. Some studies that corroborate such hypothesis indicate that bacteria can travel inside wind-carried drops over a distance of $1 \mathrm{~km}$ and still remain their viability [Korzeniewska et al.., 2008,
Ekstrom S. et al.., 2010, Ahern et al., 2007, Cho and Chwang, 2011, Polymenakou 2012]. Water collected from a galvanized sheet rooftop proves to be almost free from pathogenic microbes. This of course is due to the bactericidal effects of zinc and a relatively even surface of sheet. Furthermore, the amounts of $E$. coli obtained with classic and chromogenic media are noteworthy. In most cases more bacteria grew on the latter one (Tables 2, 3, 4).

In temperate climates the amount of bacteria is variable and depends mainly on the temperature and humidity [Niewolak and Mindrow, 2006]. Figure 1 illustrates the seasonal variation of a detected E. coli. The optimum temperature for growth of pathogenic microorganisms (mainly inhabited by warm-blooded organisms) is close to $37{ }^{\circ} \mathrm{C}$. In the early spring and spring season the number of these bacteria growing in the water with tiled roofs and from the air. In the summer 


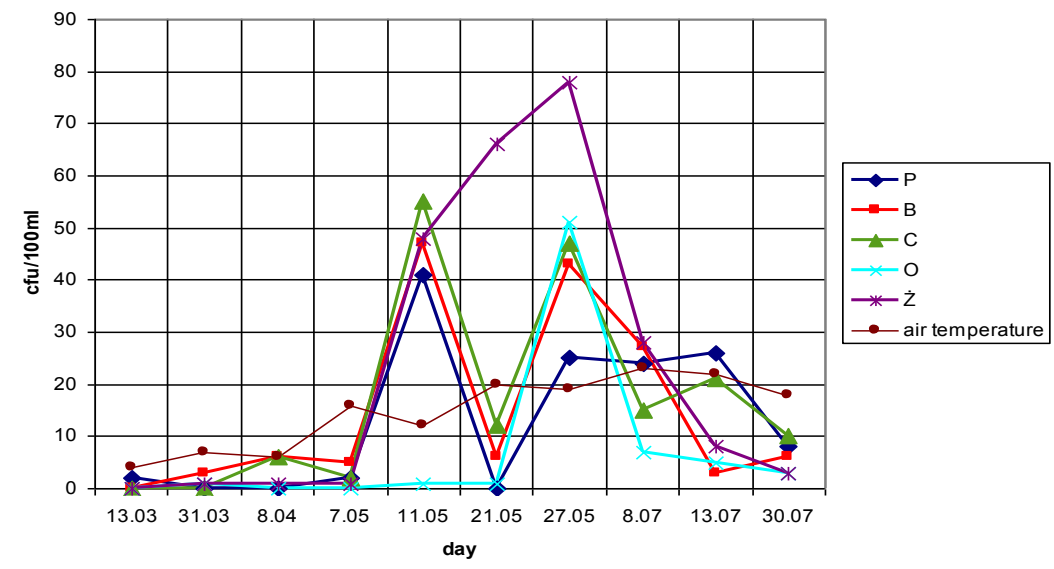

Figure 1. Changes in the number of E. coli bacteria during the season spring-summer

season was a decrease in the amount, despite the absence of an express temperature fluctuations. This may be due to excessive heat roofs.

An important indicator for microbial quality of water is also the overall bacteria count determined usually with the plate method. Performed studies suggest that on standard nutrient medium only some of live bacteria in a tested sample cultivate. Employing enriched agar R and extending incubation time led to significantly higher numbers of colonies (Tables 5, 6, 7).

Plate methods, however, are very time-consuming and highly error-prone, because most of live bacteria cultivate in laboratory conditions, which renders the results unreliable [Krøjgaard, 2011]. In a study of microbiology rainwater method is used Real-Time PCR (Kaushik and Balasubramanian 2012, Ahmed at al., 2014).

Table 4. Pathogenic bacteria count in rainwater - summer (13 July 2015)

\begin{tabular}{|l|c|c|c|c|c|}
\hline \multirow{2}{*}{\multicolumn{1}{c|}{ Indicator }} & \multicolumn{5}{c|}{ The number of bacteria in 100 ml water sample [cfu] } \\
\cline { 2 - 7 } & $\mathrm{P}$ & $\mathrm{B}$ & $\mathrm{C}$ & $\mathrm{O}$ & Z \\
\hline E. coli (standard substrate) & 8 & 6 & 10 & 63 & 87 \\
\hline E. coli (chromogenic substrate) & 8 & 25 & 12 & 8 & 23 \\
\hline streptococcus faecalis & 0 & 55 & 12 & 63 & 89 \\
\hline Clostridium perfingens & 0 & 0 & 0 & 0 & 0 \\
\hline
\end{tabular}

Table 5. Bacteriological test results for rainwater - early spring (13 March 2015)

\begin{tabular}{|c|c|c|c|c|c|c|c|}
\hline \multirow{2}{*}{$\begin{array}{c}\text { Water } \\
\text { sample }\end{array}$} & \multicolumn{2}{|c|}{$\begin{array}{c}\text { Psychrophilic bacteria } \\
{[\mathrm{cfu} / \mathrm{ml} \text { ] }}\end{array}$} & \multicolumn{2}{c|}{$\begin{array}{c}\text { Mesophilic bacteria } \\
\text { [cfu/ml] }\end{array}$} & \multicolumn{3}{c|}{$\begin{array}{c}\text { Flow cytometry } \\
\text { [counts/ml] }\end{array}$} \\
\cline { 2 - 8 } & Agar „A" & Agar „R” & Agar „A" & Agar „R” & SG $^{*}$ & JP $^{* *}$ & Totality $^{* * *}$ \\
\hline P & 0 & 300 & 0 & 0 & 13250 & 5050 & 8200 \\
\hline B & 0 & 900 & 0 & 0 & 21021 & 1951 & 19070 \\
\hline C & 0 & 60 & 0 & 0 & 18400 & 1400 & 17000 \\
\hline O & 630 & 700 & 0 & 0 & 11064 & 640 & 10424 \\
\hline Ż & 78 & 165 & 0 & 0 & 1906 & 256 & 1650 \\
\hline
\end{tabular}

Table 6. Bacteriological test results for rainwater - spring (11 May 2015)

\begin{tabular}{|c|c|c|c|c|c|c|c|}
\hline \multirow{2}{*}{$\begin{array}{c}\text { Water } \\
\text { sample }\end{array}$} & \multicolumn{2}{|c|}{$\begin{array}{c}\text { Psychrophilic bacteria } \\
\text { [cfu/ml] }\end{array}$} & \multicolumn{2}{c|}{$\begin{array}{c}\text { Mesophilic bacteria } \\
\text { [cfu/ml] }\end{array}$} & \multicolumn{3}{c|}{$\begin{array}{c}\text { Flow cytometry } \\
{[\text { counts/ml] }}\end{array}$} \\
\cline { 2 - 8 } & Agar „A" & Agar „R” & Agar „A” & Agar „R” & SG $^{*}$ & JP $^{* *}$ & Totality*** $^{* *}$ \\
\hline P & 19500 & 38000 & 2100 & 5500 & 226700 & 46700 & 180000 \\
\hline B & 2900 & 289000 & 490 & 600 & 468000 & 150000 & 318000 \\
\hline C & 7500 & 18100 & 1000 & 300 & 348000 & 58000 & 290000 \\
\hline O & 1500 & 3700 & 300 & 400 & 22500 & 4500 & 18000 \\
\hline Z & 24300 & 29000 & 800 & 3000 & 61200 & 2200 & 59000 \\
\hline
\end{tabular}


Table 7. Bacteriological test results for rainwater - summer (13 July 2015)

\begin{tabular}{|c|c|c|c|c|c|c|c|}
\hline \multirow{2}{*}{$\begin{array}{c}\text { Water } \\
\text { sample }\end{array}$} & \multicolumn{2}{|c|}{$\begin{array}{c}\text { Psychrophilic bacteria } \\
\text { [cfu/ml] }\end{array}$} & \multicolumn{2}{c|}{$\begin{array}{c}\text { Mesophilic bacteria } \\
\text { [cfu/ml] }\end{array}$} & \multicolumn{3}{c|}{$\begin{array}{c}\text { Flow cytometry } \\
\text { [counts/ml] }\end{array}$} \\
\cline { 2 - 7 } & Agar „A" & Agar „R" & Agar „A” & Agar „R” & SG $^{*}$ & JP $^{\star *}$ & Totality $^{* * *}$ \\
\hline P & 13500 & 16000 & 140 & 220 & 13000 & 16000 & 29000 \\
\hline B & 15000 & 19800 & 256 & 310 & 43800 & 1200 & 45000 \\
\hline C & 26100 & 28900 & 189 & 195 & 30250 & 1250 & 31500 \\
\hline O & 1200 & 1870 & 110 & 271 & 180 & 700 & 2500 \\
\hline Ż & 16000 & 23000 & 1780 & 1740 & 332500 & 118000 & 450500 \\
\hline
\end{tabular}

* SG - total number of cells with nucleic acid

** JP - total number of dead cells with nucleic acid

*** Totality - total number of living cells $/ \mathrm{ml}$

Flow cytometry was used to assay the actual cell count. The method so far has been utilized mainly in laboratory diagnostics for assays of apoptopic and unusual (carcinogenic) bacteria counts. Indications of the numbers of live bacteria obtained with cytometry for each tested water and for each collection period were even a few times higher. The largest differences were revealed for early spring season and the most similar for spring. This is probably due to the fact that the activity of most micro-temperate (including bacteria) are significantly reduced at low temperatures $\left(0-10{ }^{\circ} \mathrm{C}\right)$ and their proliferation on the medium is not very effective. Flow cytometry also allows you to mark those cells that reproduce in the laboratory [Hammes F. et al., 2008; Steinberg M. et al., 2013]. Much smaller amounts of mesophilic bacteria in relation to psychrophilic result of moderate temperatures, even in the summer.

Due to the above normal psychrophilic and mesophilic bacteria, including faecal waste, tested water from rainfall is not suitable for drinking (Dz.U of 25 February, item. 257). Also, in the agricultural use of water with a relatively high content of coliforms and faecal streptococci and C. perfingens, it poses a threat to human health (Dz.U of 25 February, item. 257)

There are already many developed methods of disinfection of rainwater for household and agriculture. Used solar panels - it is possible to thermal inactivation of pathogenic bacteria (Amin and Han, 2009, 2011), as well as membrane filtration downstream such waters from the surface of the roof (Naddeo at al., 2013) or sand filters (Neto at al, 2012). Chemical methods such as chlorination (Neto at al, 2012), the use of silver ions (Navaz et al., 2012).

\section{CONCLUSIONS}

1. Rainwater at the time going through the outside air is contaminated microbiologically, which is associated with the presence of bioaerosol.

2. Rainwater collected from roofs have a large load of microbiological pollution, including dangerous to the health of faecal bacteria.

3 . The presence of bacteria of faecal origin precludes the use of rainwater for drinking and watering plants whose fruits are in contact with the ground, and household water collected from roofs can serve only that for the purpose of cleaning in the bypass.

4. It is possible to use rainwater in horticulture agriculture, in industry and for the purpose of cleaning, preferably after its disinfection (physical or chemical).

5. It is advisable to use alternative methods for determining the quality and quantity of microorganisms in order to obtain more reliable results of these assays.

\section{REFERENCES}

1. Ahern, H.E., Walsh, K.A., Hill, T.C.J., Moffett, B.F., 2007. Fluorescent pseudomonads isolated from cloud and rain water produce biosurfactants. Biogeosciences 4, 115-124.

2. Ahmed W., Brandes H., Gyawali P., Sidhu J.P.S., Toze S., 2014. Opportunistic pathogens in roofcaptured rainwater samples, determined using quantitative PCR, Water Research 53, 361-369,

3. Amin M.T., Han M.Y. 2009. Roof-harvested rainwater for potable purposes: Application of solar collector disinfection (SOCO-DIS), Water Research 43, 5225-5235. 
4. Amin M.T., Han M.Y. 2011. Improvement of solar based rainwater disinfection by using lemon and vinegar as catalysts. Desalination.

5. Cho, B.C., Hwang, C.Y., 2011. Prokaryotic abundance and 16S rRNA gene sequences detected in marine aerosols on the East Sea (Korea). FEMS Microbiol. Ecol. 76, 327-341.

6. Determining the total celi count and quantitative ratios of high and low nucleic acid content cells in freshwater using flow cytometry, Federal Office of Public Health, December 2012.

7. Ekstrom S., Noziere B., Hultberg M., Alsberg T., Magner J., Nilsson E.D., Artaxo P., 2010. A possible role of ground-based microorganisms on cloud formation in the atmpsphere, Biogeosciences 7 , 387-394.

8. Gikas Georgios D., Tsihrintzis Vassilios A. 2012. Assesment of water quality of first - flush roof runoff and harvested rainwater. Journal of Hydrology.

9. Hammes F., Berney M., Wang Y., Vital M., Koster O., Egli T. 2008. Flow-cytomefric total bacterial cell counts as a descriptive microbiological parameter for drinking water treatment processes. Water Res 42, 269-277.

10. Helmreich B., Horn 2008. Opportinities in rainwater harvesting. Desalination.

11. Kaushik R., Balasubramanian R., 2012. Assesment of Bacterial phatogens in fresh rainwater and airborne particulate matter using Real - Time PCR. Atmospheric Environment.

12. Korzeniewska E., Filipowska Z., Gotkowska Płachta A., Janczukowicz W., Ritkowski B., 2008. Bacteriological pollution of the atmospheric air at the municipial and dairy Wasterwater Treatment Plant area and in its surroundings.

13. Lee J. Y., Yang J-S, Han M., Choi J. 2010. Comparsion of the microbiological anh chemical characterization of harvested rainwater and reservoir water as alternative water resources. Science of the Total Environment.

14. Lee M., Tansel B., Balbin M. 2011. Influence of residential water use efficiency measures on houshold water dem and: A four year longitudinal study.
Resources, Conservation and Recycling 56: 1-6. DOI:10.1016/j.resconrec.2011.08.006.

15. Naddeo V., Scannapieco D., Belgiorno V., 2013. Enhanced drinking water supply through harvested rainwater treatment, Journal of Hydrology 498, 287-291.

16. Nawaz M., Han M.Y., Kim T., Manzoor U., Amin M.T. 2012. Silver disinfection of Pseudomonas aeruginosa and Escherichia coli in rooftop harvested rainwater for potable purposes. Science of the Total Environment.

17. Neto R.F., Calijuri M.L., Carvalho I., Rainwater treatment in airports using slow sand filtration followed by chlorination: Efficiency and costs Aníbal da Fonseca Santiago, Resources, Conservation and Recycling 65, 124-129, 2012

18. Niewolak S., Mindrow M. 1998. Season changes of survival of Escherichia coli, Streptococcus faeccrlis. Salmonella typhimurium and Salmonella typhi of dublin in lake water. Polish Joumal of Ervironmental Studies, 7, 1, 27-34.

19. Regulation of the Minister of the Environment of 6 February 2015 on municipal sewage sludge (Dz.U of 25 February, iteam. 257).

20. Regulation of the Minister of Health of 13 November on the quality of water intended for human consumption (Dz.U. of 12 November, item. 1989.

21. Polymenakou, P.N., 2012. Atmosphere: a source of pathogenic or beneficial microbes Atmosphere 3, 87-102.

22. Steinberg M., Kohler D., Gohde R., 2013. Flow Cytometric enumeration of total bacterial cell count (TCC) in drinking water with the Partec CyFIow Cube 6 flow cytometer, Gorlitz.

23. Śmigielska M. 2010. Zoonoses transmitted by birds Undomesticated, Ornis Polonica, 51, 149-162.

24. Wilbers G-J, Zita Sebesvari, Andrea Rechenburg, Fabrice G. Renaud, 2013. Effects of local and spatial conditions on the quality of harvested rainwater in the Mekong Delta, Vietnam, Environmental Pollution 182, 225-232. 